Section Editor

Robert C. Griggs, MD
WriteClick: Editor's Choice
Editors' Note: In their article "Cognitive outcome of patients with classic infantile Pompe disease receiving enzyme therapy," Ebbink et al. reported data consistent with Drs. Spiridigliozzi et al.'s findings that CNS glycogen does not significantly impair cognitive function through the middle childhood years but may be related to delayed processing speed. Drs. Walters et al. report the results of their investigation into possible etiologies behind chocolate consumption lowering stroke risk.

Megan Alcauskas, MD, and Robert C. Griggs, MD

\section{COGNITIVE OUTCOME OF PATIENTS WITH CLASSIC INFANTILE POMPE DISEASE RECEIVING ENZYME THERAPY}

Gail A. Spiridigliozzi, James H. Heller, Priya S. Kishnani, Durham, NC: We would like to inquire whether glycogen impairs cognitive function. In addition, since enzyme replacement therapy (ERT) does not cross the blood-brain barrier, does cognitive function decline over time? The data of Ebbink et al. ${ }^{1}$ suggest that glycogen in the CNS does not significantly impair cognitive function. This finding is consistent with an earlier report of 13 infants with infantile Pompe who responded positively to the first year of ERT and showed stable cognitive function at the lower end of the normal range. ${ }^{2}$ Additionally, stable function was reported within the lower end of the normal range for 7 children treated with long-term ERT for 6.75 years, on average. ${ }^{3}$ Scores on a standardized measure of adaptive functioning, negatively affected by motor performance, were below IQ scores. Both research teams identified a particular weakness in processing speed and the need for developmental and educational support services, longterm cognitive surveillance, and neuroimaging studies.

Author Response: Ans T. Van der Ploeg, B.J. Ebbink, F.K. Aarsen, C.M. van Gelder, J.M.P. Van den Hout, Rotterdam, the Netherlands: Our study ${ }^{1}$ confirmed Spiridigliozzi et al.'s,3 findings of normal or mildly delayed IQ scores in children with classic infantile Pompe disease treated with ERT. This is important because ERT cannot cross the blood-brain barrier. The longest follow-up reported by Spiridigliozzi et al. ${ }^{3}$ was 9 years and 11 months; ours was 12 years and 3 months.
Although Spiridigliozzi et al. ${ }^{2}$ found a correlation between cognitive and motor development, test limitations prevented them from determining whether lower cognition was caused by motor disabilities or weak cognition. Our more suitable nonmotor intelligence tests of 2 tetraplegic teenagers revealed the influence of severe motor disabilities on developmental scores. These teenagers previously had the lowest possible mental development scores during their first 4 years, but now scored normal or mildly delayed.

Similar to the findings of Spiridigliozzi et al., ${ }^{2}$ we also found delayed processing speed. Conceivably, these delays are explained by white matter changes like those on the MRIs we reported.

Although mild delays may develop over time, infantile Pompe disease differs substantially from other lysosomal storage diseases where progressive storage in the CNS and profound mental retardation occur at an early age.

\section{(C) 2013 American Academy of Neurology}

1. Ebbink BJ, Aarsen FK, van Gelder CM, et al. Cognitive outcome of patients with classic infantile Pompe disease receiving enzyme therapy. Neurology 2012;78:1512-1518.

2. Spiridigliozzi GA, Heller JH, Case LE, Jones HN, Kishnani PS. Early cognitive development in children with infantile Pompe disease. Mol Genet Metab 2012;105:428-432.

3. Spiridigliozzi GA, Heller JH, Kishnani PS. Cognitive and adaptive functioning of children with infantile Pompe disease treated with enzyme replacement therapy: long-term follow-up. Am J Med Genet C Semin Med Genet 2012; 160:22-29.

\section{CHOCOLATE CONSUMPTION AND RISK OF STROKE: A PROSPECTIVE COHORT OF MEN AND META-ANALYSIS}

Matthew R. Walters, Catherine Williamson, Kathryn Lunn, Alison Munteanu, Glasgow, UK:

Larsson et al. ${ }^{1}$ investigated the association between chocolate consumption and risk of stroke in men, concluding that moderate chocolate consumption may lower the risk of stroke. We performed a prospective mechanistic study that may suggest a potential mechanism for this observation.

We investigated the acute effects of a bar $(100 \mathrm{~g})$ of dark or milk chocolate upon cerebrovascular reactivity in healthy volunteers. The flavanol content of the dark and milk chocolate was $104 \mathrm{mg}$ and $32 \mathrm{mg}$ of epicatechin, 


\section{Neurology}

\section{Cognitive outcome of patients with classic infantile Pompe disease receiving enzyme therapy}

Gail A. Spiridigliozzi, Ans T. Van der Ploeg, James H. Heller, et al. Neurology 2013;80;1173

DOI 10.1212/WNL.0b013e31828b8af0

This information is current as of March 18, 2013

\section{Updated Information \& Services}

References

Permissions \& Licensing

Reprints including high resolution figures, can be found at: http://n.neurology.org/content/80/12/1173.1.full

This article cites 3 articles, 1 of which you can access for free at: http://n.neurology.org/content/80/12/1173.1.full\#ref-list-1

Information about reproducing this article in parts (figures,tables) or in its entirety can be found online at:

http://www.neurology.org/about/about_the_journal\#permissions

Information about ordering reprints can be found online: http://n.neurology.org/subscribers/advertise

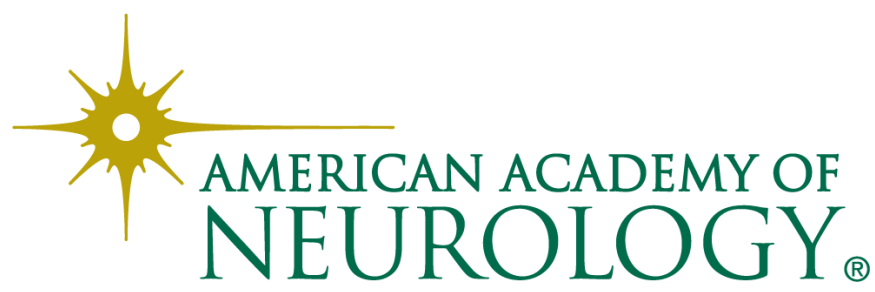

